\title{
Updated Evidence on the Mechanisms of Resistance to ALK Inhibitors and Strategies to Overcome Such Resistance: Clinical and Preclinical Data
}

\author{
Gouji Toyokawa Takashi Seto \\ Department of Thoracic Oncology, National Kyushu Cancer Center, Fukuoka, Japan
}

\section{Keywords}

Non-small cell lung cancer - Anaplastic lymphoma kinase . ALK inhibitors · Resistance mechanisms

\section{Summary}

Anaplastic lymphoma kinase ( $A L K$ ) rearrangement is one of the oncogenes in non-small cell lung cancer (NSCLC) identified in 2007. The PROFILE trials demonstrated that patients with $A L K$-rearranged NSCLC can be successfully treated with crizotinib, and that crizotinib is superior to chemotherapy in both first- and second-line settings. Furthermore, next-generation ALK inhibitors, such as alectinib and ceritinib, have been shown to harbor excellent efficacy for NSCLC patients with $A L K$ rearrangement. However, it is known that many cases ultimately acquire resistance to ALK inhibitors. Some potential mechanisms of resistance to ALK inhibitors are as follows: ALK dominant resistance, such as secondary mutations and copy number gain in the $A L K$ gene; activation of the bypass tracks, including EGFR, KRAS, KIT, MET, and IGF-1R. Furthermore, treatment strategies to overcome these resistance mechanisms have been proposed, and next-generation ALK inhibitors, agents which inhibit the bypass tracks, and heat shock protein 90 inhibitors are thought to be promising. Thus, clinical and pre-clinical evidence on the resistance mechanisms to ALK inhibitors and treatment strategies to overcome the resistance have been gradually obtained. Herein, we concisely review the current clinical and pre-clinical data regarding the mechanisms of resistance to ALK inhibitors and treatments to overcome such resistance.

\section{Introduction}

Lung cancer is the leading cause of cancer death in most countries. Although lung cancer is a highly malignant neoplasm with a poor prognosis, the molecular biological pathogenesis of lung cancer has been gradually elucidated. In particular, oncogenic drivers, such as epidermal growth factor receptor (EGFR), anaplastic lymphoma kinase (ALK), ret proto-oncogene (RET), c-ros oncogene 1, receptor tyrosine kinase (ROS1), and neurotrophic tyrosine kinase, receptor, type 1 (NTRK1) have been identified [1-4]. Furthermore, they have attracted much attention as being specifically targetable by kinase inhibitors, such as gefitinib for EGFR-mutated non-small cell lung cancer (NSCLC) and crizotinib for $A L K$-rearranged NSCLC $[5,6]$. It is therefore crucial to precisely examine these genetic disorders when treating lung cancer patients.

$A L K$ rearrangement is a potent oncogene in NSCLC, and it fuses with several partners, including EML4, HIP1 and TPR, resulting in a potent transforming activity in NSCLC $[2,7,8]$. ALK rearrangement accounts for approximately $5 \%$ of driver oncogenes in NSCLC, and the representative clinicopathological characteristics in patients with $A L K+$ NSCLC are as follows: a younger age, lightor non-smoker, adenocarcinoma histology, no definite racial differences in the frequency of the $A L K$ rearrangement, and mutually exclusive with other driver oncogenes [2,9]. The partners which fuse with ALK contain the coiled coil domain, which is dispensable for the constitutive oligomerization of the fusion protein in cells, resulting in increased oncogenicity via the aberrant activation of downstream signaling, such as the Ras/MAPK, PI3K/AKT, and JAK/STAT pathways $[2,10]$.

Pre-clinical and clinical data demonstrated that patients with $A L K+$ NSCLC can be successfully treated with ALK inhibitors such as crizotinib, alectinib, and ceritinib. Crizotinib is a first-in-class ALK tyrosine kinase inhibitor and has been shown to be potent in $A L K+$ NSCLC patients, with tolerable toxicities $[11,12]$. Further- 
more, 2 randomized phase III trials demonstrated the superiority of crizotinib to standard chemotherapy in both first- and secondline settings $[6,13]$. In addition to crizotinib, next-generation ALK inhibitors, such as alectinib and ceritinib, have been developed, and their efficacy in $A L K+$ lung cancer has been demonstrated [14, 15]. More importantly, both alectinib and ceritinib harbor anti-tumor activity in crizotinib-resistant $A L K+\operatorname{NSCLC}[15,16]$.

Despite the excellent efficacy of ALK inhibitors in patients with $A L K+$ lung cancer, resistance to ALK inhibitors is a major concern when treating $A L K+$ NSCLC patients. The mechanisms of resistance to ALK inhibitors can be divided into 2 types: ALK dominant or ALK non-dominant [17]. ALK dominant resistance mechanisms include secondary mutations and copy number gain (CNG) in the $A L K$ gene; ALK non-dominant resistance mechanisms include the activation of bypass tracks, such as EGFR, Kirsten rat sarcoma viral oncogene homolog (KRAS), v-kit Hardy-Zuckerman 4 feline sarcoma viral oncogene homolog (KIT), met protooncogene (MET), and insulin-like growth factor 1 receptor (IGF1R). Furthermore, treatment strategies to overcome the resistance mechanisms to ALK inhibitors have been proposed, and nextgeneration ALK inhibitors, agents which inhibit the bypass tracks, and heat shock protein 90 (HPS90) inhibitors are thought to be promising [18].

Therefore, both clinical and pre-clinical evidences on the resistance mechanisms to ALK inhibitors and treatment strategies to overcome the resistance have been gradually obtained. We herein concisely review the current clinical and pre-clinical data regarding the mechanisms of resistance to ALK inhibitors and the treatment strategies to overcome such resistance.

\section{ALK Inhibitors}

\section{Crizotinib}

Crizotinib was originally developed as a c-MET inhibitor, and it was later found to inhibit ALK $[19,20]$. In the expanded cohort of the PROFILE1001 trial, 143 lung cancer patients with ALK rearrangement were treated with crizotinib, and the response rate and progression-free survival (PFS) were 60.8\% (95\% confidence interval (CI) 52.3-68.9) and 9.7 months (95\% CI 7.7-12.8), respectively [12]. Although the overall survival (OS) data were immature, the estimated OS at 6 and 12 months was as high as $87.9 \%$ (95\% CI 81.3-92.3) and 74.8\% (95\% CI 66.4-81.5), respectively. Furthermore, the PROFILE1007 trial was conducted to compare crizotinib with chemotherapy (pemetrexed or docetaxel) in $A L K+$ patients previously treated with platinum-based chemotherapy [6]. 347 patients with $A L K+$ lung cancer were enrolled in the study, and 173 and 174 patients were randomized into groups receiving crizotinib and chemotherapy, respectively. PFS achieved by crizotinib was significantly longer than that achieved by chemotherapy (7.7 vs. 3.0 months, respectively; hazard ratio (HR) for progression or death with crizotinib $0.49,95 \%$ CI $0.37-0.64, \mathrm{p}<0.001)$. The objective response rates in the 2 arms were $65 \%$ (95\% CI 58-72) and $20 \%$ (95\% CI 14-26), respectively ( $\mathrm{p}<0.001)$. No significant differences were observed in the OS between crizotinib and chemotherapy (20.3 and 22.8 months, respectively), possibly due to the small number of events noted during the follow-up period and the crossover in patients treated with chemotherapy to crizotinib as part of a separate study.

The results from PROFILE1014, a randomized phase III trial which compared the first-line use of crizotinib with cisplatin or carboplatin plus pemetrexed, were recently published [13]. 172 and 171 patients were assigned to the crizotinib and chemotherapy groups, respectively. PFS, which was a primary endpoint, was 10.9 and 7.0 months (HR for progression or death with crizotinib, 0.45 , $95 \%$ CI $0.35-0.60, \mathrm{p}<0.001)$, respectively, with the response rates in both arms being 74 and $45 \%$, respectively. Similar to PROFILE1007, median OS was not reached, and the probability of 1 -year survival in the crizotinib and chemotherapy groups was 84 and 79\% (HR for death with crizotinib, 0.82 , 95\% CI 0.54-1.26, $\mathrm{p}=$ 0.36 ), respectively. Thus, crizotinib was established as first- and second-line treatment for $A L K+$ lung cancer.

\section{Second-Generation ALK Inhibitors}

Several second-generation ALK inhibitors have been developed and are currently under evaluation in clinical trials. Alectinib (CH5424802) is a very selective inhibitor of ALK as well as RET $[21,22]$, and the AF-001JP trial investigating the safety and efficacy of alectinib was conducted in Japan [14]. 46 lung cancer ALK inhibitor-naive patients with the $A L K$ rearrangement, which was identified by both fluorescence in situ hybridization and immunohistochemistry or reverse transcription polymerase chain reaction, were treated with $300 \mathrm{mg}$ alectinib twice daily. Intriguingly, the objective response rate and PFS were as high and long as 93.5\% (95\% CI 66.4-81.5) and 27.7 months (95\% CI 26.9-not evaluable), respectively. With regard to ceritinib, among $114 A L K+$ lung cancer patients treated with at least $400 \mathrm{mg}$ of ceritinib per day, objective response rate and PFS were 58\% (95\% CI 48-67) and 7.0 months (95\% CI 5.6-9.5), respectively [15]. 34 crizotinib-naïve and 80 crizotinib-treated patients achieved response rates of 62 and $56 \%$, respectively. Intriguingly, ceritinib was active even when the resistance mechanism was unknown. Very importantly, both alectinib and ceritinib have been shown to be effective for crizotinib-resistant patients, with response rates of 55 and $56 \%$, respectively [15, 16]. In addition to these agents, several ALK inhibitors, such as AP26133, ASP3062, X-396, and PF-06463922, are currently under evaluation [23-26]. However, at present, it remains to be elucidated which inhibitor would achieve the longest PFS as a first-line ALK inhibitor, and on-going phase III trials, such as the ALEX study comparing alectinib with crizotinib, will clarify whether next-generation ALK inhibitors are superior to crizotinib or not.

\section{Resistance Mechanisms to ALK Inhibitors}

Almost all $A L K+$ lung cancer patients who are successfully treated with ALK inhibitors experience resistance to the inhibitors, and this resistance is therefore the most crucial issue to resolve. As 
Camidge and Doebele [17] previously described, the mechanisms of resistance to ALK inhibitors can be divided into 2 groups: ALK dominant, which means 'still harboring addiction to ALK signaling' or ALK non-dominant, which means 'activation of bypass tracks'. ALK dominant mechanisms include secondary mutations in the $A L K$ gene and CNG, and ALK non-dominant mechanisms include the activation of EGFR, KRAS, KIT, MET, and IGF-1R pathways. The frequency of ALK dominant resistance mechanisms to crizotinib is 50\%: secondary $A L K$ mutations, $31 \%$; CNG, $13 \%$; both secondary $A L K$ mutations and CNG, 6\% [27], and the remaining 50\% are ALK non-dominant. Although much insight into the frequency and distribution of resistance mechanisms to crizotinib has been obtained, the resistance mechanisms to alectinib and ceritinib and their frequency and distribution remain to be fully elucidated.

In this section, we review the resistance mechanisms to ALK inhibitors identified in both clinical and pre-clinical settings.

\section{ALK Dominant}

Secondary mutations in the ALK gene are representative of ALK dominant resistance mechanisms. Choi et al. [28] first identified 2 secondary mutations in the ALK gene (C1156Y and L1196M) in a patient with $A L K+$ lung cancer who had progressed on crizotinib. Basic experiments confirmed that these mutations confer resistance to crizotinib: BA/F3 cells, murine interleukin-3-dependent pro-B cell lines expressing mutant forms of EML4-ALK with C1156Y and L1196M, were resistant to crizotinib, whereas the cells expressing primary EML4-ALK were successfully inhibited in a dose-dependent manner with crizotinib. Importantly, an analysis of the crystal structure of the kinase domain of ALK demonstrated that L1196 is located at the bottom of the ATP-binding pocket and that the L1196M mutation with a bulky side chain results in the interference of crizotinib binding to ALK. Intriguingly, the L1196M mutation corresponds to gatekeeper mutations in the $B C R-A B L$ fusion gene (T315I) and in the EGFR gene (T790M) [29, 30]. As shown in table 1 , more than 10 mutations in the $A L K$ gene have been so far identified to confer resistance to crizotinib: L1196M, G1269A, C1156Y, F1174L, 1151Tins, L1152R, S1206Y, I1171T, G1202R, D1203N, and V1180L [17, 31, 32, 34, 39].

With regard to the secondary $A L K$ mutations which confer resistance to alectinib, 2 mutations at codons 1171 and 1202 were identified [32-35]. 3 groups reported that the mutations at I1171 (I1171T, I1171N, and I1171S) confer resistance to alectinib, and the structural analysis revealed that disruption of a hydrogen bond between alectinib and E1167 by the I1171T mutation contributed to the destabilization of the alectinib complex with the mutant kinase [32, 34, 35]. Importantly, the mutations at codon 1171 also mediate crizotinib resistance, which can be overcome by ceritinib [32, 34]. Although V1180L also mediated a high resistance to alectinib in a cell line model, the mutation has yet to be identified in patients [34].

Friboulet et al. [36] examined 11 biopsied tumors in ceritinibresistant patients, and secondary mutations including F1174C/V and G1202R were identified in 5 (45.5\%) samples. Interestingly, F1174V and G1202R were found in 2 different sites in 1 patient, which suggests heterogeneity of resistance mechanisms in a single
Table 1. Secondary mutations in the $A L K$ gene mediating resistance to crizotinib, alectinib, and ceritinib

\begin{tabular}{lll}
\hline Crizotinib & Alectinib & Ceritinib \\
\hline L1196M [28] & I1171N/S/T [32, 34, 35] & C1156Y [36] \\
C1156Y [28] & G1202R [33] & F1174C/V [36] \\
G1269A [40] & V1180L [34] & 1151Tins? [15, 36] \\
F1174L [56] & & L1152R [36] \\
1151Tins [37] & & G1202R [36] \\
L1152R [57] & & \\
S1206Y [37] & & \\
I1171T [32, 34] & & \\
V1180L [34] & & \\
D1203N [39] & \\
G1202R [37] & \\
\hline
\end{tabular}

patient. Furthermore, it is remarkable that G1202R (which is postulated to be on the solvent-exposed region of the ALK kinase domain near the crizotinib-binding site) mediates resistance to crizotinib, alectinib, and ceritinib possibly by diminishing the binding affinity of ALK inhibitors to the mutant ALK through steric hindrance due to the presence of a large basic residue [36, 37]. In addition, a G1123S mutation in the ALK gene, which is known to induce resistance to TAE684, an ALK inhibitor in a neuroblastoma cell line, was identified to possibly mediate resistance to ceritinib $[38,39]$. Codon 1123 is located in the glycine-rich loop, and mutations at codon 1123 appear to sterically block ATP binding and/or alter the dynamics of the glycine-rich loop, resulting in perturbation of the interactions with ALK inhibitors, which require a particular conformation of the loop for binding [39]. In vitro analyses demonstrated that C1156Y, 1151Tins, and L1152R also mediate resistance to ceritinib [36].

With regard to CNG of the fusion gene, 2 of 11 patients with $A L K+$ lung cancer who acquired resistance to crizotinib were reported to exhibit new onset $A L K C N G$, which may occur in combination with the $A L K$ resistance mutations [40]. In contrast to this finding, ALK CNG has yet to be reported for alectinib- and ceritinib-resistant cancers.

Although brain metastases are sometimes called a 'sanctuary' in $A L K \pm$ lung cancer, recent evidence has shown the efficacy of ALK inhibitors, specifically alectinib, against brain metastases, which suggest that they are not necessarily a sanctuary $[14,16]$. Detailed data regarding the efficacy of ALK inhibitors for brain metastases are not provided in this review article.

\section{ALK Non-Dominant}

As well as $A L K$ secondary mutations, clinical and pre-clinical data have demonstrated newly identified resistance mechanisms to ALK inhibitors in an ALK non-dominant manner (table 2). The data regarding resistance to crizotinib include EGFR mutation [40], KRAS mutation [40], activation of the ErbB family through phosphorylation [37], amplification of KIT [37], activation of the insulin-like growth factor 1 receptor (IGF-1R) pathway [41], EGFR ligands [42], hypoxia-induced epithelial-mesenchymal transition (EMT) [43], and autophagy [44]. 
Table 2. Mechanisms conferring resistance for crizotinib, alectinib, and ceritinib

$\begin{array}{ll}\begin{array}{l}\text { Crizotinib resistance } \\ \text { Secondary mutations in the ALK } \\ \text { gene [e.g. 21] }\end{array} & \text { EGFR mutation [40] } \\ \text { ALK CNG [40] } & \text { KRAS mutation [40] } \\ \text { activation of ErbB family [37] } & \text { amplification of KIT [37] } \\ & \text { activation of IGF-1R pathway [41] } \\ & \text { EGFR ligands [42] } \\ & \text { hypoxia-induced EMT [43] } \\ & \text { autophagy [44] }\end{array}$

\section{Alectinib resistance \\ Secondary mutations in the $A L K$ gene [32-35]}

\section{Ceritinib resistance \\ Secondary mutations in the $A L K$ gene $[36,38]$}

$\mathrm{ALK}=$ Anaplastic lymphoma kinase; $\mathrm{CNG}=$ copy number gain; $\mathrm{CNS}=$ central nervous system; EGFR = epidermal growth factor receptor; KRAS = Kirsten rat sarcoma viral oncogene homolog; KIT = v-kit Hardy-Zuckerman 4 feline sarcoma viral oncogene homolog; IGF-1R = insulin-like growth factor 1 receptor; $\mathrm{EMT}=$ epithelial-mesenchymal transition; $\mathrm{HGF}=$ hepatocyte growth factor; $\mathrm{MET}=$ met proto-oncogene.

With regard to the EGFR and KRAS mutations, Doebele et al. [40] investigated the resistance mechanisms to crizotinib in 11 of 14 patients with $A L K+$ lung cancer who experienced progressive disease on crizotinib. The EGFR and KRAS mutations were observed in 1 and 2 patients, respectively. An EGFR L858R mutation in 1 patient was found only in the post-crizotinib biopsy sample, and not in the initial biopsy sample, suggesting the involvement of the EGFR mutation in the acquired resistance to crizotinib. While 1 patient was shown to harbor the KRAS mutation prior to crizotinib treatment and have an intrinsic resistance to crizotinib, another KRAS mutation was identified only in re-biopsied sample without any evidence of a preexisting mutation in KRAS. In line with this report, a case with concomitant $A L K$ rearrangement and KRAS mutation at codon 12 was intrinsically insensitive to crizotinib [45].

Cell line models and the investigation of patient-derived samples before and after crizotinib therapy showed the involvement of increased ErbB signaling through phosphorylation in the acquired resistance to crizotinib [37]. In 4 of 9 cases whose tumor samples were analyzed before and after crizotinib treatment, phospho-receptor tyrosine kinase arrays identified increased phospho-EGFR and phospho-ERBB3 levels in the resistant tumor compared with the corresponding sensitive tumor, which was confirmed by an immunoblotting assay using antibodies detecting phospho-EGFR and phospho-ERBB3. Intriguingly, in 1 patient with increased EGFR activation, a secondary $A L K$ mutation was concomitantly identified, suggesting the possibility of heterogeneity of resistance mechanisms in a single patient. KIT amplification was also reported to induce resistance to crizotinib, which may require an increased ex- pression of the KIT ligand stem cell factor [37]. In 2 patients with KIT amplification in post-crizotinib samples, increased phosphorEGFR and a secondary $A L K$ mutation were identified, supporting the notion of multiple and diverse mechanisms of tyrosine kinase inhibitor (TKI) resistance within each individual patient.

Activation of the IGFR-1R pathway was also reported to be involved in the resistance to crizotinib [41]. The experience of 1 $A L K+$ case successfully treated with IGF-1R-specific antibody and the following pre-clinical experiments showed the possible involvement of the activated IGF-1R and the adaptor insulin receptor substrate 1 pathway in the resistance to crizotinib and X-376, an ALK inhibitor. 4 of 5 tumor samples taken at the time of acquired resistance to crizotinib displayed increased levels of pIGF-1R, which indicates activation of the IGF-1R pathway. Other possible resistance mechanisms identified by pre-clinical investigation include EGFR ligands, EMT, and autophagy, whose significance in clinical settings remains unclear [42-44]. In addition, Giri et al. [46] identified novel mutations of 7 genes (CSMD3, CDKN2A, MAGI1, CREBBP, DOT1L, PBX1, and PRKDC) in a crizotinib-resistant tumor sample; however, their role in the acquired resistance to crizotinib was unclear due to the lack of data before the administration of crizotinib and the lack of basic experiments.

With regard to the involvement of alternate signaling pathways in the acquisition of resistance to next-generation ALK inhibitors, few reports exist thus far [43, 47-49]. In particular, the involvement of hepatocyte growth factor (HGF)/MET signaling pathway activation in the acquired resistance to alectinib has been demonstrated by several groups [47-49]. In our institution, we experienced an alectinib-resistant patient who was successfully treated with the crizotinib therapy, and intriguingly, $M E T$ amplification was observed in the re-biopsy sample of hepatic metastases after failure of alectinib, suggesting that $M E T$ amplification may act as an alternative signal, thereby conferring resistance to alectinib, and it may thus be overcome by crizotinib [47]. Furthermore, pre-clinical data by 2 groups demonstrated that HGF, a ligand of MET, induces resistance to alectinib, but not to crizotinib, via activation of MET signaling in in vitro analyses [48, 49]. These findings suggest that activation of MET signaling may serve as a salvage signal after alectinib treatment, which is possibly not observed in crizotinib-resistance due to the high inhibitory activity of crizotinib against MET [19, 20]. As well as crizotinib-resistance, other groups have demonstrated that EGFR ligands and hypoxia-induced EMT confer resistance to alectinib $[43,48]$. The resistance mechanism via the bypass track has yet to be reported in ceritinib-resistant patients or cells, which should therefore be investigated in clinical and pre-clinical settings.

\section{Strategies to Overcome the Resistance}

As shown above, there is growing evidence for the existence of resistance mechanisms, and the establishment of individual treatment strategies to overcome these mechanisms is essential. In this section, the possible treatment options to overcome such resistance are discussed. 


\section{Next-Generation ALK Inhibitors}

The efficacy of next-generation ALK inhibitors in crizotinib-resistant patients has been demonstrated by clinical and pre-clinical data $[15,16,31,36]$. With regard to secondary ALK mutations, alectinib and ceritinib have been shown to be able to inhibit various types of mutated ALK including L1196M with lower $\mathrm{IC}_{50}$ than crizotinib $[31,36]$. In clinical settings, the efficacy of ceritinib in patients with crizotinib-resistance via L1196M, G1269A, 1151Tins (which is inconsistent with in vitro data as shown in [36]), S1206Y, and amplified $A L K$ was confirmed; furthermore, ceritinib was effective in crizotinib-resistant patients without any $A L K$ mutations or amplification [15]. Alectinib was also shown to be effective for crizotinib-resistant patients with a response rate of $55 \%$, although resistance mechanisms to crizotinib were not mentioned in the trial [16]. However, given that G1202R is insensitive to crizotinib, alectinib, and ceritinib compared with other secondary mutations, sequential treatment with alectinib or ceritinib following failure of crizotinib therapy via G1202R is thought not to be able to overcome crizotinib resistance. In fact, this mutation was shown to induce resistance to alectinib and ceritinib in patients [33,36]. Intriguingly, AP26113 and PF-06463922 were reported to harbor anti-tumor activity in cells with the G1202R mutation, demonstrating the possible use of these inhibitors after failure of crizotinib, alectinib, and ceritinib through G1202R [26, 50]. In addition, resistance to crizotinib by mutations at codons 1171 and 1174 may not be overcome by alectinib and ceritinib, respectively, given the findings that these mutations confer resistance to alectinib and ceritinib [32, 34-36]. Katayama et al. [34] demonstrated the efficacy of ceritinib in a patient with resistance to alectinib via the I1171T mutation. Experimental models confirmed this finding and showed that V1180L-mediated alectinib resistance is also overcome by ceritinib. Additionally, ceritinib was shown to overcome the resistance via the activated IGF-1R pathway because of its high inhibitory activity against IGF-1R as well as ALK [41]. With regard to the use of alectinib for ceritinibresistance, alectinib was shown to be effective for resistance to ceritinib mediated via a G1123S mutation in the ALK gene [38].

\section{HSP90 Inhibitors}

HSP90 is a molecular chaperone that contributes to the correct folding of a number of newly synthesized polypeptides and unstable folded proteins and the prevention of their misaggregation [51]. Furthermore, EML4-ALK with and without the gatekeeper mutation was shown to be a client protein of the HSP90 chaperone [52]. Importantly, in vitro analyses showed that HSP90 inhibitors, such as ganetespib and 17-AAG, demonstrate anti-tumor activity for not only wild type EML4-ALK but also the mutated EML4ALK with L1196M and F1174L mutations [52-54]. Clinically, objective responses to ganetespib and AUY922 were reported in patients with crizotinib-resistant $A L K$-rearranged NSCLC [54, 55]. Furthermore, 17-DMAG, one of the HSP90 inhibitors, was shown to be able to overcome alectinib-resistance that is mediated by receptor ligands, such as EGFR ligands and HGF [48]. As a result, it is possible that patients with resistance to ALK inhibitors may benefit from HSP90 inhibitors.

\section{Inhibition of Alternative Bypass Signaling}

The inhibition of alternative bypass signals, including KIT, MET, and IGF-1R, seems to play an important role in the treatment of patients with resistance to ALK inhibitors. For instance, cell-based analyses demonstrated that imatinib (KIT-TKI) and OSI-906 (IGF-1R-TKI) combined with crizotinib were reported to salvage bypass signal-induced resistance to crizotinib or X-376 via the KIT and IGF-1R pathways, respectively [37, 41]. With regard to resistance to crizotinib mediated by activation of the EGFR pathway, concurrent use of EGFR-TKIs with crizotinib is thought to be effective [37]. Additionally, AP26113, which is a dual inhibitor of the mutant activated forms of the $A L K$ and EGFR genes, as well as TKI-resistant forms (including L1196M of the ALK gene and T790M of the EGFR gene) might harbor anti-tumor activity in patients with resistance to ALK inhibitors via the EGFR mutations. However, since these data were generated by in vitro analyses or conceptual studies only, they should be clarified in clinical settings. With regard to alectinib resistance via activation of the HGF/MET signaling pathway, Kogita et al. [49] showed that concurrent administration of a MET inhibitor with alectinib enhances the sensitivity to alectinib in cell-based models.

\section{Crizotinib as a MET Inhibitor}

As mentioned above, in vitro experiments demonstrated the association of the activation of the HGF/MET pathway with alectinib resistance; crizotinib as well as HSP90 inhibitors were shown to be able to overcome HGF-mediated resistance to alectinib [48, 49]. In fact, we experienced an $A L K+$ patient who was successfully treated with crizotinib, which was originally developed as a MET inhibitor, following the acquisition of resistance to alectinib via the possible mechanism of MET amplification [47]. These findings underline the significance of the activated HGF/MET pathway in alectinib resistance which can be overcome by inhibition of MET. Furthermore, crizotinib should be considered as a possible treatment option after acquisition of alectinib resistance through activation of the HGF/MET pathway.

\section{Conclusion}

We herein described the mechanisms of resistance to ALK inhibitors and the possible treatment strategies to overcome such resistance. Although ALK inhibitors are very effective for patients with ALK+ NSCLC, almost all patients eventually become resistant. Thus, it is a crucial and emergent issue to establish strategies to overcome the resistance according to each resistance mechanism. Importantly, a re-biopsy after the failure of ALK inhibitors should be encouraged to gain more insight into the resistance mechanisms and to properly treat patients who are resistant to ALK inhibitors.

\section{Acknowledgement}

We thank Brian Quinn for providing critical comments on the manuscript. 


\section{Disclosure Statement}

Dr. Seto received honoraria from Chugai Pharmaceutical Co., Ltd., Pfizer Japan Inc., and Novartis Pharma K.K., as well as research funding from Chugai Pharmaceutical Co., Ltd., Pfizer Japan Inc., and Novartis Pharma K.K.; Dr. Toyokawa received honoraria from Chugai Pharmaceutical Co., Ltd. and Pfizer Japan Inc.

\section{References}

1 Lynch TJ, Bell DW, Sordella R, Gurubhagavastula S, Okimoto RA, Brannigan BW, Harris PL, Haserlat SM, Supko JG, Haluska FG, Louis DN, Christiani DC, Settleman J, Haber DA: Activating mutations in the epidermal growth factor receptor underlying responsiveness of non-small-cell lung cancer to gefitinib. $\mathrm{N}$ Engl J Med 2004;350:2129-2139.

2 Soda M, Choi YL, Enomoto M, Takada S, Yamashita Y, Ishikawa S, Fujiwara S, Watanabe H, Kurashina K, Hatanaka H, Bando M, Ohno S, Ishikawa Y, Aburatani H, Niki T, Sohara Y, Sugiyama Y, Mano H: Identification of the transforming EML4-ALK fusion gene in non-small-cell lung cancer. Nature 2007;448:561-566.

3 Takeuchi K, Soda M, Togashi Y, Suzuki R, Sakata S, Hatano S, Asaka R, Hamanaka W, Ninomiya H, Uehara H, Lim Choi Y, Satoh Y, Okumura S, Nakagawa K, Mano H, Ishikawa Y: RET, ROS1 and ALK fusions in lung cancer. Nat Med 2012;18:378-381.

4 Vaishnavi A, Capelletti M, Le AT, Kako S, Butaney M, Ercan D, Hahale S, Davies KD, Aisner DL, Pilling AB, Berge EM, Kim J, Sasaki H, Park SI, Kryukov G, Garraway LA, Hammerman PS, Haas J, Andrews SW, Lipson D, Stephens PJ, Miller VA, Varella-Garcia M, Jänne PA, Doebele RC: Oncogenic and drug-sensitive NTRK1 rearrangements in lung cancer. Nat Med 2013; 19:1469-1472.

5 Mitsudomi T, Morita S, Yatabe Y, Negoro S, Okamoto I, Tsurutani J, Seto T, Satouchi M, Tada H, Hirashima T, Asami K, Katakami N, Takada M, Yoshioka H, Shibata K, Kudoh S, Shimizu E, Saito H, Toyooka S, Nakagawa K, Fukuoka M; West Japan Oncology Group: Gefitinib versus cisplatin plus docetaxel in patients with non-small-cell lung cancer harbouring mutations of the epidermal growth factor receptor (WJTOG3405): an open label, randomised phase 3 trial. Lancet Oncol 2010;11:121-128.

6 Shaw AT, Kim DW, Nakagawa K, Seto T, Crinó L, Ahn MJ, De Pas T, Besse B, Solomon BJ, Blackhall F, Wu YL, Thomas M, O'Byrne KJ, Moro-Sibilot D, Camidge DR, Mok T, Hirsh V, Riely GJ, Iyer S, Tassell V, Polli A, Wilner KD, Jänne PA: Crizotinib versus chemotherapy in advanced ALK-positive lung cancer. N Engl J Med 2013;368:2385-2394.

7 Hong M, Kim RN, Song JY, Choi SJ, Oh E, Lira ME Mao M, Takeuchi K, Han J, Kim J, Choi YL: HIP1ALK, a novel fusion protein identified in lung adenocarcinoma. J Thorac Oncol 2014;9:419-422.

8 Choi YL, Lira ME, Hong M, Kim RN, Choi SJ, Song JY, Pandy K, Mann DL, Stahl JA, Peckham HE, Zheng Z, Han J, Mao M, Kim J: A novel fusion of TPR and ALK in lung adenocarcinoma. J Thorac Oncol 2014;9:563566.

9 Gainor JF, Varghese AM, Ou SH, Kabraji S, Awad MM, Katayama R, Pawlak A, Mino-Kenudson M, Yeap BY, Riely GJ, Iafrate AJ, Arcila ME, Ladanyi M, Engelman JA, Dias-Santagata D, Shaw AT: ALK rearrangements are mutually exclusive with mutations in EGFR or KRAS: an analysis of 1,683 patients with non-small cell lung cancer. Clin Cancer Res 2013;19:4273-4281.
Mano H: Non-solid oncogenes in solid tumors: EML4ALK fusion genes in lung cancer. Cancer Sci 2008;99: 2349-2556.

11 Kwak EL, Bang YJ, Camidge DR, Shaw AT, Solomon B, Maki RG, Ou SH, Dezube BJ, Jänne PA, Costa DB, Varella-Garcia M, Kim WH, Lynch TJ, Fidias P, Stubbs H, Engelman JA, Sequist LV, Tan W, Gandhi L, MinoKenudson M, Wei GC, Shreeve SM, Ratain MJ, Settleman J, Christensen JG, Haber DA, Wilner K, Salgia R, Shapiro GI, Clark JW, Iafrate AJ: Anaplastic lymphoma kinase inhibition in non-small-cell lung cancer. N Engl J Med 2010;363:1693-1703.

12 Camidge DR, Bang YJ, Kwak EL, Iafrate AJ, VarellaGarcia M, Fox SB, Riely GJ, Solomon B, Ou SH, Kim DW, Salgia R, Fidias P, Engelman JA, Gandhi L, Jänne PA, Costa DB, Shapiro GI, Lorusso P, Ruffner K, Stephenson P, Tang Y, Wilner K, Clark JW, Shaw AT: Activity and safety of crizotinib in patients with ALK-positive non-small-cell lung cancer: updated results from a phase 1 study. Lancet Oncol 2012;13:1011-1019.

13 Solomon BJ, Mok T, Kim DW, Wu YL, Nakagawa K, Mekhail T, Felip E, Cappuzzo F, Paolini J, Usari T, Iyer S, Reisman A, Wilner KD, Tursi J, Blackhall F; PROFILE 1014 Investigators: First-line crizotinib versus chemotherapy in ALK-positive lung cancer. N Engl J Med 2014;371:2167-2177.

14 Seto T, Kiura K, Nishio M, Nakagawa K, Maemondo $\mathrm{M}$, Inoue $\mathrm{A}$, Hida $\mathrm{T}$, Yamamoto $\mathrm{N}$, Yoshioka $\mathrm{H}$, Harada M, Ohe Y, Nogami N, Takeuchi K, Shimada T, Tanaka T, Tamura T: CH5424802 (RO5424802) for patients with ALK-rearranged advanced non-smallcell lung cancer (AF-001JP study): a single-arm, openlabel, phase 1-2 study. Lancet Oncol 2013;14:590-598.

15 Shaw AT, Kim DW, Mehra R, Tan DS, Felip E, Chow LQ, Camidge DR, Vansteenkiste J, Sharma S, De Pas T, Riely GJ, Solomon BJ, Wolf J, Thomas M, Schuler M, Liu G, Santoro A, Lau YY, Goldwasser M, Boral AL, Engelman JA: Ceritinib for ALK-rearranged non-smallcell lung cancer. N Engl J Med 2014;370:1189-1197.

16 Gadgeel SM, Gandhi L, Riely GJ, Chiappori AA, West HL, Azada MC, Morcos PN, Lee RM, Garcia L, Yu L, Boisserie F, Di Laurenzio L, Golding S, Sato J, Yokoyama S, Tanaka T, Ou SH: Safety and activity of alectinib against systemic disease and brain metastases in patients with crizotinib-resistant ALK-rearranged non-small-cell lung cancer (AF-002JG): results from the dose-finding proportion of a phase $1 / 2$ study. Lancet Oncol 2014;15:1119-1128.

17 Camidge DR, Doebele RC: Treating ALK-positive lung cancer - early success and future challenges. Nat Rev Clin Oncol 2012;9:268-277.

18 Toyokawa G, Seto T: ALK inhibitors: what is the best way to treat patients with ALK+ non-small-cell lung cancer? Clin Lung Cancer 2014;15:313-319.

19 McDermott U, Iafrate AJ, Gray NS, Shioda T, Classon M, Maheswaran S, Zhou W, Choi HG, Smith SL, Dowell L, Ulkus LE, Kuhlmann G, Greninger P, Christensen JG, Haber DA, Settleman J: Genomic alterations of anaplastic lymphoma kinase may sensitize tumors to anaplastic lymphoma kinase inhibitors. Cancer Res 2008;68:3389-3395.
0 Cui JJ, Tran-Dubé M, Shen H, Nambu M, Kung PP, Pairish M, Jia L, Meng J, Funk L, Botrous I, McTigue M, Grodsky N, Ryan K, Padrique E, Alton G,Timofeevski S, Yamazaki S, Li Q, Zou H, Christensen J, Mroczkowski B, Bender S, Kania RS, Edwards MP: Structure based drug design of crizotinib (PF-02341066), a potent and selective dual inhibitor of mesenchymal-epithelial transition factor (c-MET) kinase and anaplastic lymphoma kinase (ALK). J Med Chem 2011;54:6342-6363.

21 Sakamoto H, Tsukaguchi T, Hiroshima S, Kodama T, Kobayashi T, Fukami TA, Oikawa N, Tsukuda T, Ishii N, Aoki Y: CH5424802, a selective ALK inhibitor capable of blocking the resistant gatekeeper mutant. Cancer Cell 2011;19:679-690.

22 Kodama T, Tsukaguchi T, Satoh Y, Yoshida M, Watanabe Y, Kondoh O, Sakamoto H: Alectinib shows potent antitumor activity against RET-rearranged nonsmall cell lung cancer. Mol Cancer Ther 2014;13: 2910-2919.

23 Solomon B, Wilner KD, Shaw AT: Current status of targeted therapy for anaplastic lymphoma kinase-rearranged non-small cell lung cancer. Clin Phamacol Ther 2013;95:15-23.

24 Mori M, Kuromitsu S, Ueno Y, Tanaka R, Shimada I, Kondoh Y, Konagai S, Sakagami H, Fushiki H, Saito R, Sengoku T: ASP3026, a selective ALK inhibitor, induces tumor regression in a crizotinib-refractory model and prolongs survival in an intrapleurally xenograft model. Ann Meet Proc AACR 2012;abstr 866.

25 Lovly CM, Heuckmann JM, de Stanchina E, Chen H, Thomas RK, Liang C, Pao W: Insights into ALKdriven cancers revealed through development of novel ALK tyrosine kinase inhibitors. Cancer Res 2011;71: 4920-4931.

26 Johnson TW, Richardson PF, Bailey S, Brooun A, Burke BJ, Collins MR, Cui JJ, Deal JG, Deng YL, Dinh D, Engstrom LD, He M, Hoffman J, Hoffman RL, Huang Q, Kania RS, Kath JC, Lam H, Lam JL, Le PT, Lingardo L, Liu W, McTigue M, Palmer CL, Sach NW, Smeal T, Smith GL, Stewart AE, Timofeevski S, Zhu H, Zhu J, Zou HY, Edwards MP: Discovery of (10R)-7-amino-12-fluoro2,10,16-trimethyl-15-oxo-10,15,16,17-tetrahydro-2H-8,4(metheno)pyrazolo(4, 3-h) $(2,5,11)$-benzoxadiazacyclotetradecine-3-carbonitrile (PF-06463922), a macrocyclic inhibitor of anaplastic lymphoma kinase (ALK) and c-ros oncogene 1 (ROS1) with preclinical brain exposure and broad-spectrum potency against ALK-resistant mutations. J Med Chem 2014;57:4720-4744.

27 Rossi A, Maione P, Sacco PC, Sgambato A, Casaluce F, Ferrara ML, Palazzolo G, Ciardiello F, Gridelli C: ALK inhibitors and advanced non-small cell lung cancer (review). Int J Oncol 2014;45:499-508.

28 Choi YL, Soda M, Yamashita Y, Ueno T, Takashima J, Nakajima T, Yatabe Y, Takeuchi K, Hamada T, Haruta H, Ishikawa Y, Kimura H, Mitsudomi T, Tanio Y, Mano H; ALK Lung Cancer Study Group: EML4-ALK mutations in lung cancer that confer resistance to ALK inhibitors. N Engl J Med 2010;363:1734-1739. 
29 Gorre ME, Mohammed M, Ellwood K, Hsu N, Paquette R, Rao PN, Sawyers CL: Clinical resistance to STI-571 cancer therapy caused by BCR-ABL gene mutation or amplification. Science 2001;293:876-880

30 Pao W, Miller VA, Politi KA, Riely GJ, Somwar R, Zakowski MF, Kris MG, Varmus H: Acquired resistance of lung adenocarcinomas to gefitinib or erlotinib is associated with a second mutation in the EGFR kinase domain. PLoS Med 2005;2:e73.

-31 Kodama T, Tsukaguchi T, Yoshida M, Kondoh O, Sakamoto H: Selective ALK inhibitor alectinib with potent antitumor activity in models of crizotinib resistance. Cancer Lett 2014;351:215-221.

-32 Toyokawa G, Hirai F, Inamasu E, Yoshida T, Nosaki K, Takenaka T, Yamaguchi M, Seto T, Takenoyama M, Ichinose Y: Secondary mutations at I1171 in the ALK gene confer resistance to both crizotinib and alectinib. J Thorac Oncol 2014;9:e86-e87.

33 Ignatius Ou SH, Azada M, Hsiang DJ, Herman JM, Kain TS, Siwak-Tapp C, Casey C, He J, Ali SM, Klempner SJ, Miller VA: Next-generation sequencing reveals a novel NSCLC ALK F1174V mutation and confirms ALK G1202R mutation confers high-level resistance to alectinib (CH5424802/RO5424802) in ALK-rearranged NSCLC patients who progressed on crizotinib. J Thorac Oncol 2014;9:549-553.

34 Katayama R, Friboulet L, Koike S, Lockerman EL, Khan TM, Gainor JF, Iafrate AJ, Takeuchi K, Taiji M, Okuno Y, Fujita N, Engelman JA, Shaw AT: Two novel ALK mutations mediate acquired resistance to nextgeneration ALK inhibitor alectinib. Clin Cancer Res 2014;20:5686-5696.

- 35 Ou SH, Klempner SJ, Greenbowe JR, Azada M, Schrock AB, Ali SM, Ross JS, Stephens PJ, Miller VA: Identification of a novel HIP1-ALK fusion variant in non-small-cell lung cancer (NSCLC) and discovery of ALK I1171 (I1171N/S) mutations in two ALK-rearranged NSCLC patients with resistance to alectinib. J Thorac Oncol 2014;9:1821-1825.

36 Friboulet L, Li N, Katayama R, Lee CC, Gainor JF, Crystal AS, Michellys PY, Awad MM, Yanagitani N, Kim S, Pferdekamper AC, Li J, Kasibhatla S, Sun F, Sun X, Hua S, McNamara P, Mahmood S, Lockerman EL, Fujita N, Nishio M, Harris JL, Shaw AT, Engelman JA: The ALK inhibitor ceritinib overcomes crizotinib resistance in non-small cell lung cancer. Cancer Discov 2014;4:662-673.

37 Katayama R, Shaw AT, Khan TM, Mino-Kenudson M, Solomon BJ, Halmos B, Jessop NA, Wain JC, Yeo AT, Benes C, Drew L, Saeh JC, Crosby K, Sequist LV, Iafrate AJ, Engelman JA: Mechanisms of acquired crizotinib resistance in ALK-rearranged lung Cancers. Sci Transl Med 2012;4:120ral7.

- 38 Toyokawa G, Inamasu E, Shimamatsu S, Yoshida T, Nosaki K, Hirai F, Yamaguchi M, Seto T, Takenoyama M, Ichinose Y: Identification of a novel ALK G1123S mutation in a patient with ALK-rearranged NSCLC exhibiting resistance to ceritinib. J Thorac Oncol 2015, in press.
39 Heuckmann JM, Hölzel M, Sos ML, Heynck S, BalkeWant H, Koker M, Peifer M, Weiss J, Lovly CM, Grütter C, Rauh D, Pao W, Thomas RK: ALK mutations conferring differential resistance to structurally diverse ALK inhibitors. Clin Cancer Res 2011;17:7394-7401.

40 Doebele RC, Pilling AB, Aisner DL, Kutateladze TG, Le AT, Weickhardt AJ, Kondo KL, Linderman DJ, Heasley LE, Franklin WA, Varella-Garcia M, Camidge DR: Mechanisms of resistance to crizotinib in patients with ALK gene rearranged non-small cell lung cancer. Clin Cancer Res 2012;18:1472-1482.

41 Lovly CM, McDonald NT, Chen H, Ortiz-Cuaran S, Heukamp LC, Yan Y, Florin A, Ozretić L, Lim D, Wang L, Chen Z, Chen X, Lu P, Paik PK, Shen R, Jin H, Buettner R, Ansén S, Perner S, Brockmann M, Bos M, Wolf J, Gardizi M, Wright GM, Solomon B, Russell PA, Rogers TM, Suehara Y, Red-Brewer M, Tieu R, de Stanchina E, Wang Q, Zhao Z, Johnson DH, Horn L, Wong KK, Thomas RK, Ladanyi M, Pao W: Rationale for co-targeting IGF-1R and ALK in ALK fusion-positive lung cancer. Nat Med 2014;20:1027-1034.

42 Yamada T, Takeuchi S, Nakade J, Kita K, Nakagawa T, Nanjo S, Nakamura T, Matsumoto K, Soda M, Mano $\mathrm{H}$, Uenaka T, Yanos S: Paracrine receptor activation by microenvironment bypass survival signals and ALK inhibitor resistance in EML4-ALK lung cancer cells. Clin Cancer Res 2012;18:3592-3602.

43 Kogita A, Togashi Y, Hayashi H, Sogabe S, Terashima M, De Velasco MA, Sakai K, Fujita Y, Tomida S, Takeyama Y, Okuno K, Nakagawa K, Nishio K: Hypoxia induces resistance to ALK inhibitors in the H3122 non-small cell lung cancer cell line with an ALK rearrangement via epithelial-mesenchymal transition. Int J Oncol 2014;45:1430-1436.

44 Ji C, Zhang L, Cheng Y, Patel R, Wu H, Zhang Y, Wang M, Ji S, Belani CP, Yang JM, Ren X: Induction of autophagy contributes to crizotinib resistance in ALKpositive lung cancer. Cancer Biol Ther 2014;15:570577.

45 Anai S, Suzuki K, Ijichi K, Harada T, Toyokawa G, Seto T, Takenoyama M, Takayama K, Ichinose Y, Nakanishi Y: A Case of crizotinib-resistant lung adenocarcinoma harboring a KRAS mutation and an EML4ALK fusion gene. J Med Cases 2014;5:631-633.

46 Giri S, Patel JK, Mahadevan D: Novel mutations in a patient with ALK-rearranged lung cancer. N Engl J Med 2014;371:1655-1656.

47 Gouji T, Takashi S, Mitsuhiro T, Yukito I: Crizotinib can overcome acquired resistance to CH5424802: is amplification of the MET gene a key factor? J Thorac Oncol 2014;9:e27-28.

48 Tanimoto A, Yamada T, Nanjo S, Takeuchi S, Ebi H, Kita K, Matsumoto K, Yano S: Receptor ligand-triggered resistance to alectinib and its circumvention by Hsp90 inhibition in EML4-ALK lung cancer cells. Oncotarget 2014;5:4920-4928.
49 Kogita A, Togashi Y, Hayashi H, Banno E, Terashima M, De Velasco MA, Sakai K, Fujita Y, Tomida S, Takeyama Y, Okuno K, Nakagawa K, Nishio K: Activated MET acts as a salvage signal after treatment with alectinib, a selective ALK inhibitor, in ALK-positive nonsmall cell lung cancer. Int J Oncol 2015;46:1025-1030.

50 Rachel MS, Anjum R, Miller D, Vodala S, Moran L, Wang F, Clackson T, Garner AP, Rivera VM: AP26113 possesses pan-inhibitory activity versus crizotinib-resistant ALK mutants and oncogenic ROS1 fusions. Ann Meet Proc AACR 2013;abstract 5655

51 Taipale M, Jarosz DF, Lindquist S: HSP90 at the hub of protein homeostasis: emerging insights. Nat Rev Mol Cell Biol 2010;11:515-528.

52 Katayama R, Khan TM, Benes C, Lifshits E, Ebi H, Rivera VM, Shakespeare WC, Iafrate AJ, Engelman JA, Shaw AT: Therapeutic strategies to overcome crizotinib resistance in non-small cell lung cancers harbouring the fusion oncogene EML4-ALK. Proc Natl Acad Sci U. S. A. 2011;108:7535-7540.

53 Chen Z, Akbay E, Mikse O, Tupper T, Cheng K, Wang Y, Tan X, Altabef A, Woo SA, Chen L, Reibel JB, Janne PA, Sharpless NE, Engelman JA, Shapiro GI, Kung AL, Wong KK: Co-clinical trials demonstrate superiority of crizotinib to chemotherapy in ALK-rearranged nonsmall cell lung cancer and predict strategies to overcome resistance. Clin Cancer Res 2014;20:1204-1211.

54 Sang J, Acquaviva J, Friedland JC, Smith DL, Sequeira M, Zhang C, Jiang Q, Xue L, Lovly CM, Jimenez JP, Shaw AT, Doebele RC, He S, Bates RC, Camidge DR, Morris SW, El-Hariry I, Proia DA: Targeted inhibition of the molecular chaperone Hsp90 overcomes ALK inhibitor resistance in non-small cell lung cancer. Cancer Discov 2013;3:430-443.

55 Felip E, Carcereny E, Barlesi F, Gandhi L, Sequist LV, Kim S, Groen HJM, Besse B, Kim D, Smi EF, Akimov M, Avsar E, Bailey S, Ofosu-Appiah W, Garon EB: Phase II activity of the HSP90 inhibitor AUY922 in patients with ALK-rearranged (ALK+) or EGFR mutated advanced non-small cell lung cancer. Ann Oncol 2012; 23:ix152(abstr 4380).

56 Sasaki T, Okuda K, Zheng W, Butrynski J, Capelletti M, Wang L, Gray NS, Wilner K, Christensen JG, Demetri G, Shapiro GI, Rodig SJ, Eck MJ, Jänne PA: The neuroblastoma-associated F1174L ALK mutation causes resistance to an ALK kinase inhibitor in ALK-translocated cancers. Cancer Res 2010;70:10038-10043.

57 Sasaki T, Koivunen J, Ogino A, Yanagita M, Nikiforow S, Zheng W, Lathan C, Marcoux JP, Du J, Okuda K, Capelletti M, Shimamura T, Ercan D, Stumpfova M, Xiao Y, Weremowicz S, Butaney M, Heon S, Wilner K, Christensen JG, Eck MJ, Wong KK, Lindeman N, Gray NS, Rodig SJ, Jänne PA: A novel ALK secondary mutation and EGFR signaling cause resistance to ALK kinase inhibitors. Cancer Res 2011;71:6051-6060. 